\title{
ОБРАЗ АДРЕСАТА РЕКЛАМНОГО ТЕКСТА С ТОЧКИ ЗРЕНИЯ ПОСТУЛАТОВ РЕЧЕВОГО ОБЩЕНИЯ 1
}

\author{
THE ADDRESSEE OF AN ADVERTISING TEXT \\ AND H. P. GRICE'S EFFICIENT COMMUNICATION RULES
}

\author{
ИРИНА БАКЛАНОВА
}

\begin{abstract}
The aim of this paper is to describe the features of advertising texts, which convey implicit information about the character of their target audience. This problem can be solved by analyzing the peculiarities of using Grice's rules in texts for efficient communication. Information about the expected addressee can be expressed by such means as: (1) the degree of detailed elaboration or compression of information (Maxim of Quantity); (2) the character of argumentation or its absence (Maxim of Quality); (3) the presence or absence of the indicators of semantic relations between the parts of a given text (Maxim of Relation); (4) the character of the style of a given text and/or the language units that are used in it (Maxim of Manner).
\end{abstract}

Ирина Бакланова, Государственный институт русского языка им. А.С. Пушкина, Москва - Россия.

\section{Российский Федеральный закон о рекламе гласит:}

Реклама - информация, распространенная любым способом, в любой форме и с использованием любых средств, адресованная неопределенному кругу лиц и направленная на привлечение внимания к объекту рекламирования, формирование или поддержание интереса к нему и его продвижение на рынке [Федеральный закон о рекламе 2006].

Однако утверждение о том, что реклама адресована „неопределенному кругу лиц", может быть отнесено только к рекламе вообще, а каждая конкретная реклама, как и любой другой текст, ориентирована на определенного адресата, и образ этого адресата получает отражение в тексте с помощью различных языковых средств. Например, М.С. Алексеева говорит о том, что в случае использования в рекламе прецедентных текстов

1 Исследование выполнено при финансовой поддержке РГНФ в рамках научно-исследовательского проекта РГНФ („Коммуникативная структура текста: образ автора и образ адресата в разных типах дискурса"), проект № 08-04-00322а. 
в качестве адресата предполагается не просто „человек своего круга”, но языковая личность с достаточным уровнем коммуникативной компетентности [Алексеева 2008: 122; ср. Кохтев 1996].

Однако вопрос о том, каким образом в тексте получает отражение личность адресата, на которого рассчитывал автор, пока еще изучен мало и преимущественно на материале художественной литературы [Арутюнова 1981; Бахтин 1996; Бударагина 2006; Виноградов 1971; 1980; Шмелева 1981; Шмид 2003].

Вместе с тем, по нашим наблюдениям, образ предполагаемого адресата находит отражение и в нехудожественных текстах, например в мемуарных, научных и публицистических [Бакланова 2008а; Бакланова 2008б; Бакланова 2009].

Цель данной статьи - определить источники, из которых может быть почерпнута информация о предполагаемых адресатах различных рекламных текстов.

Материалом для исследования послужили тексты из московских рекламных газет и рекламные тексты, расклеенные в московском метро.

По нашим наблюдениям, важным инструментом для выявления образа адресата текста являются известные постулаты речевого общения Г.П. Грайса [Грайс 1985].

Как отмечает Г.П. Грайс, общение подчинено Принципу Кооперации, который он сформулировал так: „Твой коммуникативный вклад на данном шаге диалога должен быть таким, какого требует совместно принятая цель (направление) этого диалога" [Грайс 1985, 222]. Ученый вывел и более конкретные постулаты, соблюдение которых соответствует выполнению Принципа Кооперации. Это постулаты Количества, Качества, Отношения и Способа. В соответствии с Принципом Кооперации и выделенными на его основании постулатами адресат по умолчанию получает от автора информацию в соответствующем коммуникативным потребностям адресата объеме, внятно изложенную, отвечающую интересам адресата, с объяснением всего непонятного и в приемлемой форме. Г.П. Грайс разработал постулаты речевого общения, чтобы показать, как автор текста передает адресату имплицитное содержание, которое отвечает авторским намерениям. Однако на основании этих постулатов можно получать и такую информацию, которая не входила в коммуникативные намерения автора текста [ср.: Федосюк 2008]. В частности эта информация может нести сведения об отправителе текста или о его адресате.

Конкретизируем сказанное применительно к реконструкции образа адресата рекламного текста.

Постулаты категории $\mathrm{K}$ о л и ч е с т в а состоят в предписаниях: „Твое высказывание должно содержать не меньше информации, чем 
требуется (для выполнения текущих целей диалога)” и „Твое высказывание должно содержать не больше информации, чем требуется".

Признаком соблюдения постулата Количества может быть возможность подстановки в текст слов с общим смыслом: „Я передаю именно такое количество информации потому, что...". Источником сведений об образе адресата является количество информации, содержащейся в рекламном тексте.

Из сказанного следует, что короткий рекламный текст, очевидно, рассчитан на адресата, который целенаправленно ищет рекламу определенного содержания.

В свою очередь, более подробный текст предполагает адресата, который не ищет специально информации об определенных товарах и услугах. Сопоставим следующие два примера:

Алкоголизм. Запои. Лечение на дому. Кандидат мед. наук. (499) 907-8383, 9615108 Л.МКД312067 17.10.00 (Газета „Экстра М”. Выпуск „Север”. № 16 (854) 2 мая 2009 года).

Как видно из данного текста, он предполагает адресата, специально ищущего информацию о специалистах, занимающихся лечением алкоголизма, и в частности осведомлен о том, что доверия заслуживают специалисты, имеющие государственную лицензию (см. Сокращение Л.МКДЗ12067 17.10.00. в тексте).

Муж больше не пьет!!! Мой муж много лет был алкоголиком. Это при том, что раньше употреблял наркотики. Мне говорили, что лечить бесполезно. К счастью, нарколог помог нам раздобыть редкий фито-комплекс. Вскоре муж перестал напиваться в стельку, потом бросил совсем, вернулся к жизни. Сейчас может позволить себе по праздникам выпить. Как все нормальные люди, не испытывая похмелья и зависимости.

\section{Комментирует В.А. Разумовский:}

Фито-комплекс - крупнейшее открытие в борьбе с алкоголизмом, благодаря которому избавились от алкогольной зависимости уже тысячи людей по всему миру. Теперь фито-комплекс доступен у нас. Фито-комплекс восстанавливает выработку пептидов, отвечающих за нормальное состояние психики и устранение алкогольной зависимости. В результате воздействует на тягу к алкоголю, психо-эмоциональные процессы, регенерирует клетки печени, нормализует функции гипоталамуса, рекомендован даже при женском алкоголизме, возможно применение без ведома больного, применяется при сопутствующих заболеваниях.

Проконсультируйтесь со специалистом.

Информация строго конфиденциальна.

Остерегайтесь подделок! ОГРН 1057748280920.

Телефон в Москве 8 (495) 231-23-52” (Газета „ЦЕНTP PLUS”. Восток, № 14, 2009). 
Как видно из приведенного текста, он предполагает адресата, имеющего проблему, но специально не ищущего пути ее решения. Поэтому автор предлагает такому адресату информацию в привычной и понятной форме - в форме письма, где рассказывается, как конкретный человек решил свою проблему. К тому же есть разумный специалист по фамилии Разумовский, который пусть непонятно, но авторитетно рассказывает о препарате.

Постулаты категории К а ч е с т в а - это предписания: „Не говори того, что ты считаешь ложным” и „Не говори того, для чего у тебя нет достаточных оснований".

Признаком соблюдения постулата Качества может быть возможность подстановки в текст слов с общим смыслом: „Я утверждаю это потому, что...". Источником сведений об образе адресата является характер приводимой аргументации.

Из сказанного следует, что лишенная аргументации рекламная информация рассчитана на адресата, с доверием относящегося к рекламным предложениям.

Рекламный текст с аргументацией, которая содержит информацию о преимуществах данного предложения, рассчитан на менее доверчивого адресата, ищущего среди рекламных текстов оптимальных предложений.

Сопоставим следующие два примера:

Переезды, пианино, рояли, сейфы. 517-27-58 (Газета „Экстра М”. Выпуск "Север". № 13 (851), 11 апреля 2009 года).

Как видно из текста, он рассчитан на адресата, не нуждающегося в подробной аргументации.

Переезды. Приезжаем через 2 часа. Сборка-разборка, упаковка мебели, утилизация старой мебели. 510-97-64. Самые низкие цены у нас! Звоните! Все работники гражд. РФ, русские (Газета „Экстра М”. Выпуск „Север”. № 13 (851), 11 апреля 2009 года).

Как следует из текста, по мнению его автора, простое сообщение об услугах по переезду не убедит адресата в необходимости позвонить по указанному телефону. Автор считает, что адресат хочет быть уверен в правильности своего выбора. Поэтому ему нужно знать условия переезда: цену, быстроту приезда, помогут ли с мебелью и т. п.

Кроме того, как это видно из текста, адресат, на которого рассчитана данная реклама, входит в круг тех современных россиян, которые страдают ксенофобией и хотят иметь дело только с гражданами Российской Федерации, причем русскими по национальности.

Постулат категории О т н о ш е н и я заключается в единственном предписании: „Не отклоняйся от темы”. 
Из этого следует, что адресату должен быть понятен ход мыслей автора. Признаком соблюдения постулата Отношения может быть возможность подстановки в текст слов с общим смыслом: „Я перехожу к этому потому, что...". Источником сведений об образе адресата будет наличие или отсутствие причинно-следственных связей между частями текста.

Если автор в рекламном тексте соединяет факты, на первый взгляд не имеющие причинно-следственных связей, следовательно, он считает, что адресату известны рекламируемые факты и ясны отношения между ними.

Если же автор текста заботится о том, чтобы причинно-следственные связи между частями текста были явными, следовательно, он полагает, что рекламируемые факты ему неизвестны и связь между ними тоже.

Сопоставим следующие два примера:

Турция? Я это заслужила (Реклама в метро).

На первый взгляд непонятно, почему некая женщина заслужила целое государство. Однако, по мнению составителя текста, адресат этой рекламы понимает, что под словом Туриия подразумеваются современные курорты в Турции. А каждая женщина, читая эту рекламу и невольно ставя себя на место $я$, находит подтверждение тому, почему она заслужила отдых на курорте: потому что работала, воспитывала детей, вела хозяйство, боролась с невзгодами и т. д.

Турфирма „Плай": Анапа, Геленджик, Сочи по разумным ценам www.plai.ru, 514-8668, 306-5998 (Газета „Экстра М”. Выпуск „Север”. № 16 (854) 2 мая 2009 года).

Автор данной рекламы заботится о выражении причинно-следственных связей в тексте, т. к., по-видимому, считает, что иначе адресату информация будет неясна. Поэтому текст начинается с объясняющего и создающего контекст слова турфирма, а синтаксис бессоюзного предложения вносит порядок в изложение того, что предлагает эта туристическая фирма.

Постулаты категории С п о с о б а заключаются в предписаниях: „Выражайся ясно”, „Избегай непонятных выражений” и „Избегай неоднозначности".

Из постулата Способа следует, что автор должен использовать адекватный для адресата выбор языковых средств: слов, стиля, сокращений, иноязычных выражений и т. п. Признаком соблюдения постулата Способа может быть возможность подстановки в текст слов с общим смыслом: „Я использую это языковое средство в значении та- 
ком-то...". Источником сведений об образе адресата будет наличие или отсутствие объяснения значения использованных языковых средств.

Из этого вытекает, что если автор не объясняет выбранные им языковые выражения, следовательно, он рассчитывает на то, что они понятны адресату.

Если же автор разъясняет выбранные им языковые выражения, значит, он предполагает, что они могут быть непонятны адресату. Например:

Ост. балк. Дер. AL. Ваг. Шкаф. Крыша. Пол. 5186794” (Газета „Экстра M. Выпуск „Север”. № 16 (854) 2 мая 2009 года).

Как видно из текста, его автор полагал, что адресат в курсе рекламного рынка и поэтому поймет информацию, записанную сокращенно, - Остекление балконов деревом, алюминием, вагонкой. Возможно изготовление шкафов на балконе, крыши над балконом и усовершенствование балконного пола. Кроме того, он считал, что адресату известны обозначения химических элементов, в частности алюминия.

Дом окон. Светопрозрачные конструкции, деревянные, $\mathrm{AL}$, пластиковые. Остекление. AL (provedal), ПВХ (veko), дерево (финские технологии). Заводское остекление балконов, лоджий. Гарантия. Скидки до 20\%. Внутренняя и наружная отделка. Вынос, крыши, сайдинг, шкафы, утепление, кирпичная кладка, отделка фасадов искусственным камнем любой сложности. Бесплатная консультация. Скидка читателям газеты 20\%. 772-57-89. (495) 411-46-38. www.okondom.ru” (Газета „Экстра М”. Выпуск „Север”. № 13 (851) 11 апреля 2009 года).

Из текста следует, что автор этой рекламы не рассчитывал на то, что его адресат поймет сокращенные записи или не сочтет их неуважением к себе, поэтому рекламный текст записан полностью. В то же время автор полагал, что его адресат в курсе рекламного рынка окон и поэтому ему известно сокращение $\mathrm{Al}$ - химического обозначения алюминия, из которого он предпочитает разновидность provedal. Адресату известно значение аббревиатуры ПВХ и то, что особо ценны оконные рамы из этого материала фирмы veko. Адресат знает преимущества финских технологий при изготовлении рам из дерева. Адресату известно также, что такое сайдинг и вынос при остеклении балкона. К тому же адресат является пользователем Интернета.

К сказанному следует добавить, что неудачным приемом рекламного текста являются попытки прямого воздействия на адресата либо посредством императивов Покупайте! Звоните! Приезжайте!, либо при помощи безглагольных предложений Только сейчас! С уиенкой! Дешево! Например: 
С уценкой!!! 15-60\% На гарантии! Большой выбор! Холодильники, плиты, стиральные машины. Тел. (495) 775-91-49 (Строгино)- (Газета „Экстра М”. Выпуск „Север". № 13 (851), 11 апреля 2009 года).

Подобные тексты предполагают безвольного адресата, который легко поддается чужому влиянию, не думая, нужен ли ему рекламируемый товар. Скорее всего, как отмечает Е.Е. Аникин,

призыв „купи”, выраженный напрямую, т. е. эксплицитно, будет интерпретирован реципиентом (потенциальным покупателем) как попытка навязать ему чужую волю и будет отвергнут [Аникин 2006, 176].

В заключение отметим, что представление об образе адресата одного текста чаще можно получить в соответствии с Принципом Кооперации на основании сразу нескольких постулатов речевого общения. Например:

Tuborg. Выиграй Greenfest tour. 100000 призов (Реклама в метро).

Основываясь на постулате Количества, можно утверждать, что автор строит короткий рекламный текст, рассчитывая на адресата, осведомленного о рынке пива.

Постулат Качества дает основания считать, что, аргументируя выбор пива не его вкусовыми качествами, а возможностью выиграть некие призы, автор текста ориентируется на азартного адресата, склонного к лотереям.

Исходя из постулата Отношения, можно утверждать, что предполагаемый адресат рекламы хорошо осведомлен о том, что многие современные товары содержат выигрышные купоны.

Наконец, постулат Способа позволяет сделать вывод о том, что автор рекламного текста уверен, что адресат хорошо поймет, что Tuborg - это датская марка пива, a Greenfest tour - это организуемый фирмой Tuborg тур по Англии с посещением музыкального фестиваля в пригороде Лондона [см. http://www.greenfest.ru].

Таким образом, из данного текста вытекает, что он рассчитан на адресата - современного молодого человека, который хорошо ориентируется в содержании кратких рекламных текстов, разбирается в марках пива, склонен к получению призов, любит путешествия и достаточно хорошо владеет английским языком. 


\section{Литература}

А л е к с е е в а М.С., Прецедентные феномены как источник коммуникативных неудач В рекламе предприятий ресторанного бизнеса, „Политическая лингвистика”, Екатеринбург 2008, вып. (2) 25.

А н и к и н Е.Е., Тактика имплицитного сопоставления в рекламном дискурсе США, „Политическая лингвистика”, Екатеринбург 2006, вып. 20.

А р у т ю н о в а Н.Д., Фактор адресата, „Известия АН СССР. Сер. Литературы и языка" 1981, № 4 .

Б а к л а н о в а И.И., Лексическое наполнение нехудожественного текста как источник сведений о его авторе и адресате, [в:] Stowo z perspektywy jezykoznawcy i ttumacza, t. 3, Gdańsk 2008[a].

Б а к л а н о в а И.И., Образ адресата научного текста и способы его реконструкции, [в:] Człowiek. Świadomość. Komunikacja. Internet. IV Międzynarodowa konferencja naukowa "Jezyk rosyjski w przestrzeni jezzykowej i kulturowej Europy i świata", Warszawa 2008[б].

Б а к л а н о в а И.И., Образ адресата нехудожественного текста на примере мемуаров, „Русский язык в школе” 2009, № 5.

Б а х т и н М.М., Язык в художественной литературе, [в:] его же, Собрание сочинений в семи томах, т. 5, Москва 1996.

Б у д а р а г и н а Е.И., Средства создания образа адресата $b$ художественном тексте. Автореф. дисс. ...канд. филол. наук, Москва 2006.

В и н о г р а д о в В.В., О теории художественной речи, Москва 1971.

В и н о г р а д о в В.В., Стиль „Пиковой дамы”, [в:] его же, О языке художественной прозы, Москва 1980.

Г р а й с Г.П., Логика и речевое общение, [в:] Новое в зарубежной лингвистике, вып. 16: Лингвистическая прагматика, Москва 1985.

К о х т е в Н.Н., Реклама: параметры оптимального текста, [в:] Культура русской речи и эффективность общения, под ред. Л.К. Граудиной, Е.Н. Ширяева, Москва 1996.

Федеральный закон о рекламе, Принят Государственной Думой 22 февраля 2006 года, Одобрен Советом Федерации 3 марта 2006 года, [в:] электронный ресурс: http://www.zakon-o-reklame.ru/

Ф е д о с ю к М.Ю., Соблюдают ли русские постулаты речевого общения Грайса?, [в:] Язык. Культура. Общение, Москва 2008.

Ш м е л е в а Т.В., Социальныи аспект смысла предложения, „Русский язык за рубежом" 1981, № 2.

Ш м и д В., Нарратология, Москва 2003. 